\title{
Rockfall hazard and risk assessment: an example from a high promontory at the historical site of Monemvasia, Greece
}

\author{
H. Saroglou ${ }^{1}$, V. Marinos ${ }^{2}$, P. Marinos ${ }^{1}$, and G. Tsiambaos ${ }^{1}$ \\ ${ }^{1}$ School of Civil Engineering, Geotechnical Department, National Technical University of Athens, 9 Iroon Polytechniou str., \\ 15780 Athens, Greece \\ ${ }^{2}$ Departement of Geology, Aristotle University of Thessaloniki, Greece
}

Correspondence to: H. Saroglou (saroglou@ central.ntua.gr)

Received: 23 August 2011 - Revised: 3 February 2012 - Accepted: 10 February 2012 - Published: 1 June 2012

\begin{abstract}
The paper presents the kinematics of rock instability of a high limestone promontory, where the Monemvasia historical site is situated, in Peloponnese in Southern Greece. The instability phenomena poses a significant threat to the town located at the base of the slope. Rockfall episodes occurred in the past due to the relaxation of the high cliff, whereas significant undermining of the castle frontiers has been observed at the slope crest.

The predominant types of instability are of planar, wedge and toppling failure of medium to large blocks. In order to investigate the existing stability conditions and decide upon the protection measures, stability and rockfall analyses were carried out for numerous slope sections under different loading conditions and protection measures were suggested.

A rock-fall risk rating system is proposed, which is based on morphological and structural criteria of the rock mass and on vulnerability and consequences. The rating system is applied for individual sections along the slope and a risk map was produced, which depicted areas having different degree of risk against rockfall occurrences.
\end{abstract}

\section{Introduction}

The impact of rockfalls on archaeological sites and historical monuments in the Greek territory is significant, since most of the landscapes are mountainous and the sites are usually found near or on steep rock slopes. Geotechnical problems related to slope instability and the protection of historical sites in Greece have been addressed by several authors (Marinos and Koukis, 1988) and recently, among others, by Marinos et al. (2002) and Marinos and Rondoyanni (2005). The hazard of rockfalls is obviously higher in areas with intense seismic activity, where earthquakes are the principal triggering factor (Marinos and Tsiambaos, 2002).
The main scope of the paper is the presentation of a new rock-fall risk rating system, which is based on morphological and structural criteria of the rock mass and on vulnerability and consequences. This system is applied for the risk assessment of the rock slopes on the Monemvasia historical site. The archaeological site of Monemvasia in South Peloponnese, consists of a historic city situated at the foot of a $60 \mathrm{~m}$ limestone rock cliff and an ancient and a medieval city as well as the castle at the slope crest (Figs. 1 and 2). The site is a typical example with high impact of rockfalls. The city at the foot is inhabited and attracts many visitors under a high risk.

The structural conditions of the slope are mainly characterised by the relaxation of the face of the slope due to its high inclination, the spacing of discontinuities allowing the formation of large blocks prone to fall and the lack of persistency of the discontinuity planes, which results in instabilities only in specific parts of the slope. Fortunately there are a lack of weak zones, which could result in large shear failures.

The identification of similar comparable conditions resulted in the division of the slope in 5 areas, presented in Fig. 1. Additionally, cross-sections were drawn in specific locations in order to assist in the stability analysis (denoted as $\mathrm{A}$ to $\mathrm{Z}$ and shown in Fig. 11). A general assessment of the rockfall hazard was presented by Marinos et al. (2009).

Rockfalls existed long before the development of the city in the ancient time, as evidenced by the foundation of several ancient structures on large fallen blocks of rock as well as the abundance of rock fragments on the slope foot. In the recent years a number of severe rockfall events have occurred (Fig. 3a). 

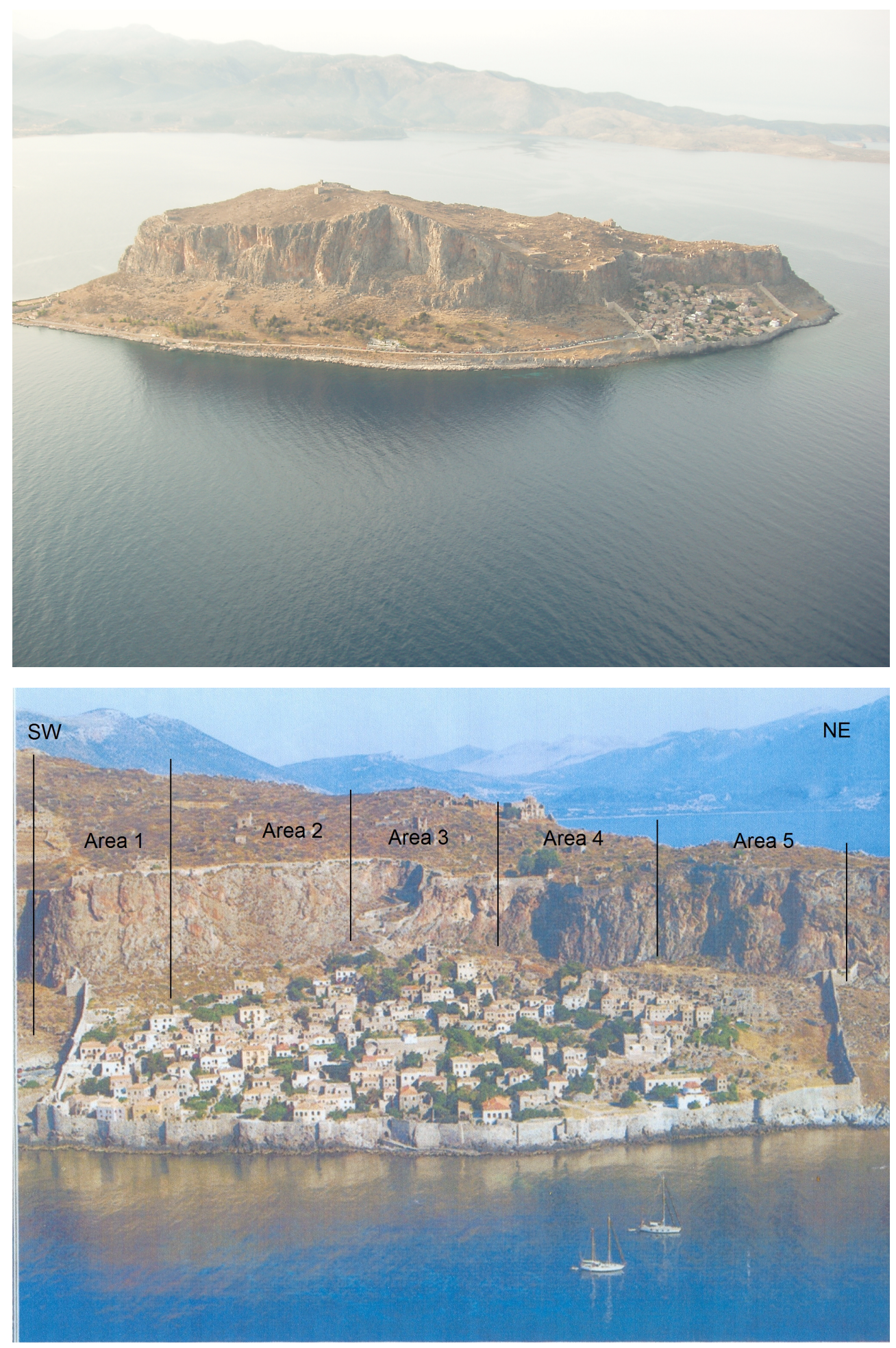

Fig. 1. (a) Panoramic view of the rock promontory, (b) close view of Monemvasia historical site. 


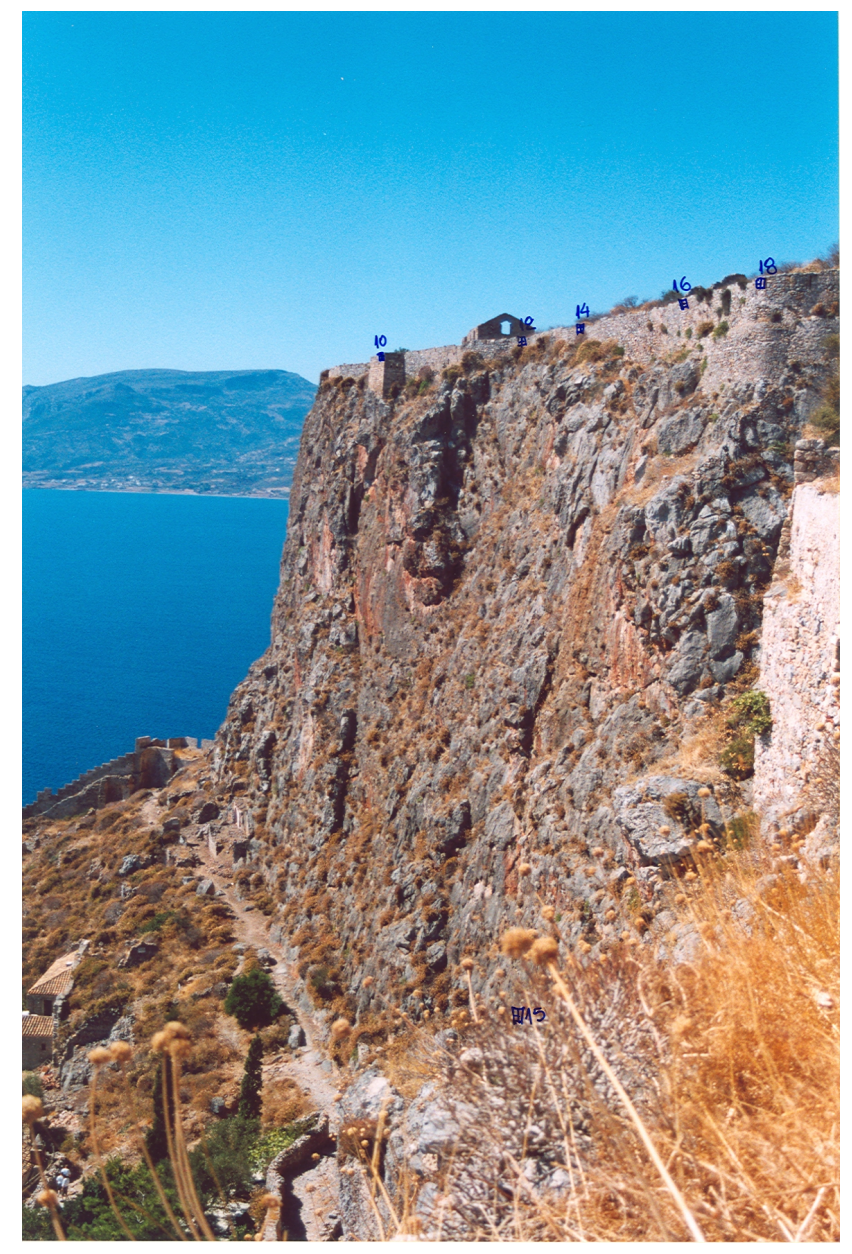

Fig. 2. Photo of a section of the high rock slope and the Monemvasia historical site (Section C in Fig. 11).

\section{Engineering geological conditions}

\subsection{General}

The geological formations encountered in the area consist of Jurassic bedded, dolomitic limestones and Cretaceous unstratified massive limestones. The rock slope overhanging the historical city consists of the Cretaceous limestone. Two major fault zones, with E-W and NE-SW strike, intersect the formation, respectively, forming the horst of the promontory.

\subsection{Rockmass conditions}

The limestone rock mass is moderately jointed, intersected by numerous major vertical fractures, which ultimately form the local face of the cliff. The limestone is karstified in places and solution voids of large dimensions are formed, undermining the rock slope.

The rock mass on the slope is intersected by three to five major discontinuity sets, as presented in the Schmidt stereographic projection in Fig. 4. These are steep in general (dip angle is greater than $60^{\circ}$ ) and two of them are parallel to the slope plane, thus, they form the rock slope face in some places. The distance of the discontinuity planes varies significantly depending on the degree of fracturing of the rock. The spacing of the discontinuities is relatively large (more than $1 \mathrm{~m}$ ); hence the sizes of the rock blocks are large to very large. In places, mainly due to stress relief the size of the rock blocks is smaller, especially on the upper part and the crest of the slope, where the wall of the upper ancient city is founded. The distance of the discontinuity planes was measured along 10 vertical scanlines of the slope face and it was determined to range between 2.5 and $10 \mathrm{~m}$, although locally the distance can be lower than $2.5 \mathrm{~m}$. The discontinuity planes are rough (JRC ranges between 4 and 12 with a mean value of 6), while the joint wall compressive strength is high (JCS is equal to $70 \mathrm{MPa}$ ). The discontinuity planes have generally no infilling material. The basic angle of friction along the discontinuities was calculated equal to $\phi=38^{\circ}$ for a stress range up to $2 \mathrm{MPa}$.

\subsection{Size of unstable rock blocks}

In order to assess the hazard against rockfalls, a detailed engineering geological mapping of the entire rock face was carried out. The scope of this mapping was to mark the main discontinuity planes on the slope and delineate the potentially unstable rock blocks, thus, allowing for a close approximation of their volume. An example of this procedure is shown in Fig. 5. The rock slope was divided in 5 distinct areas (as shown in Fig. 1) that possess (a) different slope geometry, (b) different impact type of rockfall on human activities, and (c) different engineering geological characteristics (e.g., size of potentially unstable blocks).

Based on this procedure, it was found that the most frequent rock volume of potentially unstable blocks lies between 0.5 and $1.0 \mathrm{~m}^{3}$, but with a relative frequency of $22 \%$ (out of a total number of delineated blocks equal to 343 ). The results of this statistical analysis are shown in the frequency chart in Fig. 6. Additionally, there is a large number of blocks with a volume ranging from 1.0 to $1.5 \mathrm{~m}^{3}$ and $1.5-$ $2.0 \mathrm{~m}^{3}$ (14\% and $13 \%$, respectively). The rockfall barriers, further discussed, were designed to sustain blocks up to a volume of $2.0 \mathrm{~m}^{3}$, which practically means $70 \%$ of the potentially unstable blocks.

\subsection{Rockfall history}

A number of rockfall episodes have occurred in the past. The following evidence exists: (a) Numerous blocks (volume greater than $4 \mathrm{~m}^{3}$ ) exist in the access road to the castle; (b) in section C, two recent rockfall episodes have occurred, in 2003 and in 2010 with a volume between 1 and $2 \mathrm{~m}^{3}$, which ended on a house wall in the slope base. Individual fallen blocks exist elsewhere in the perimeter of the castle. 

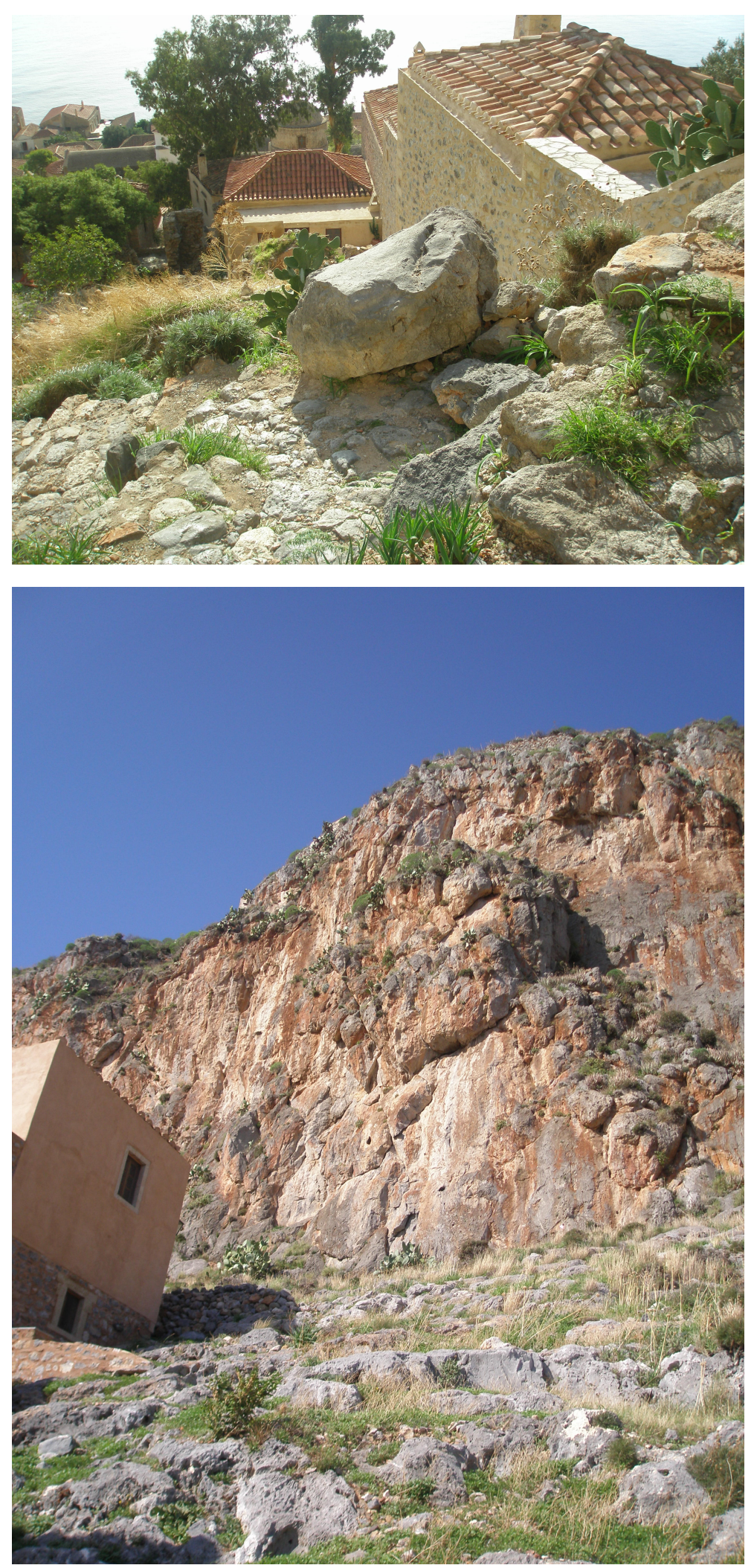

Fig. 3. (a) View of fallen rock blocks in area of section D (b) overhanging blocks in area of section Z. Range of volumes: 1.5 to $5 \mathrm{~m}^{3}$. 

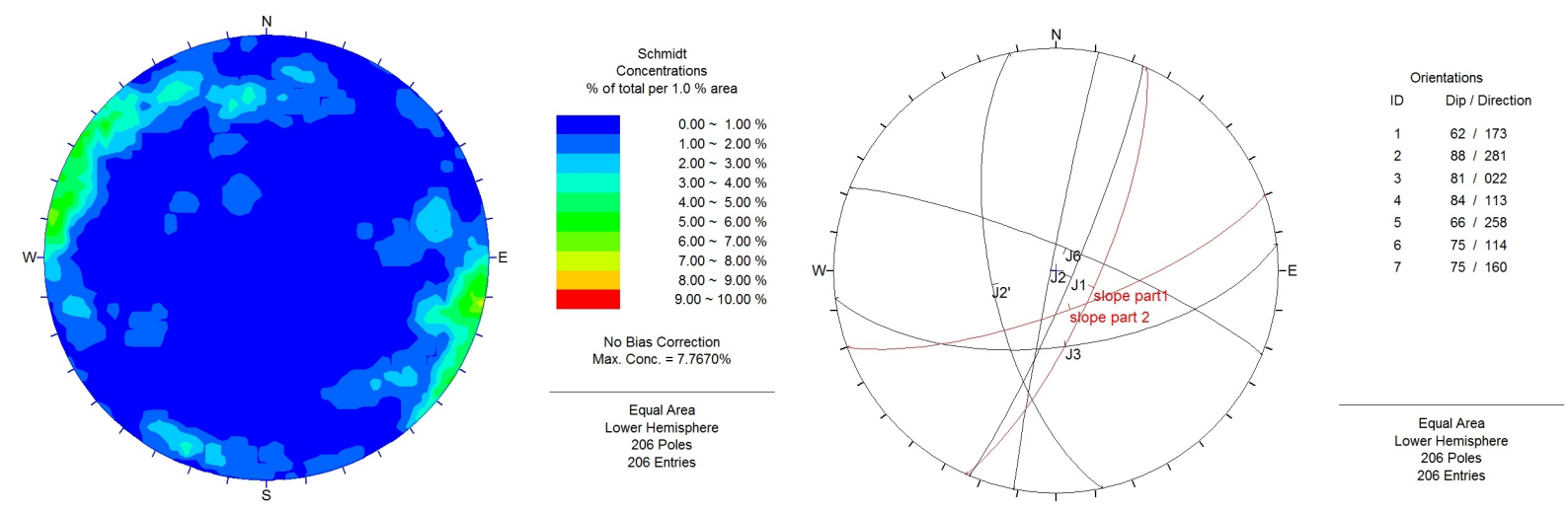

Fig. 4. Stereographic projection of main discontinuity sets and slope faces. Slope faces are denoted in red.

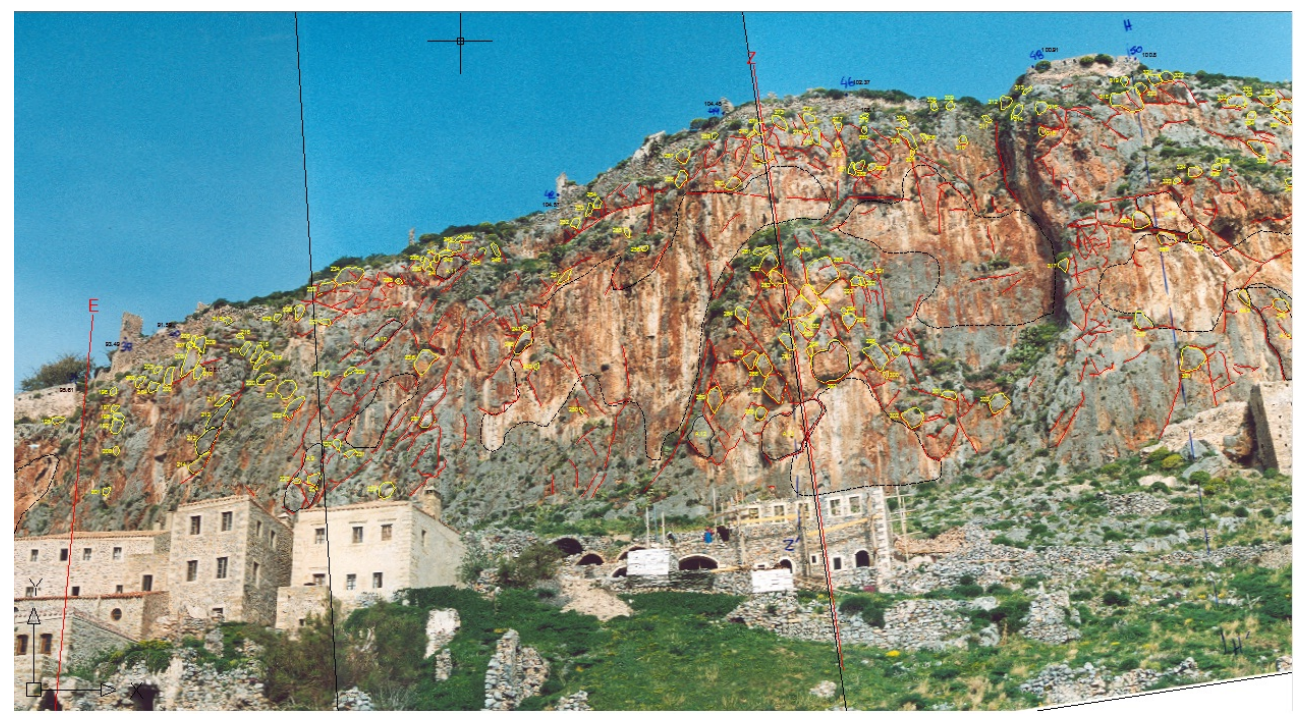

Fig. 5. Potentially unstable blocks in area 4 and 5 are shown in yellow.

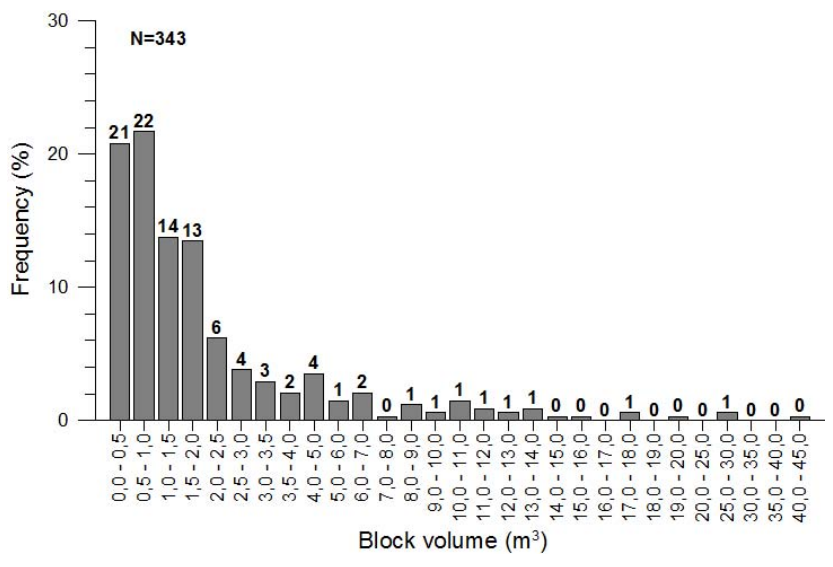

Fig. 6. Frequency chart of volume of potentially unstable rock blocks on the slope.

\section{Rockfall analysis}

\subsection{General}

The rock slope stability analyses were based on the prevailing mode of instability of each potential rock failure. The principal failure type is rockfall due to a sort of toppling, but some planar or wedge failures may also exist (Fig. 3b). The rock blocks were delineated by the engineering geological mapping and their geometry and mass was determined. Due to the inaccessible nature of the slope, the assessment of the above characteristics was based on the geodetic mapping of the rock cliff. These characteristics were grouped in five (5) areas and specific sections (A to $\mathrm{H}$ ) were formed for separate analysis (Fig. 11).

The surveying and mapping of the high rock cliff was based on a new geodetic methodology (existing geodetic surveying method and its combination by the use of 


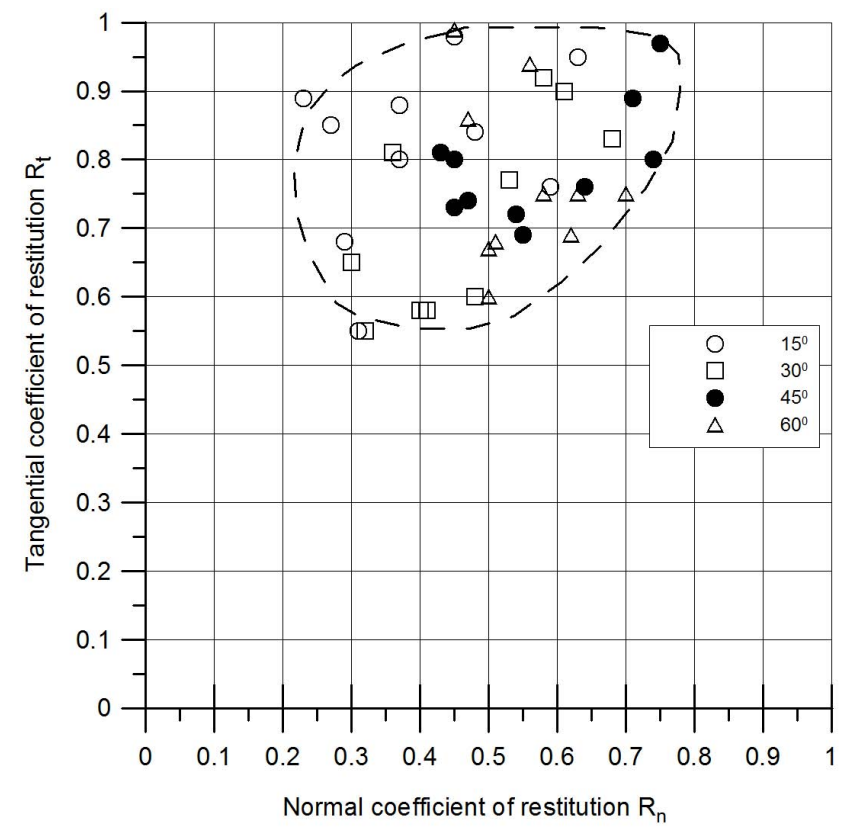

Fig. 7. Range of restitution coefficients, $R_{\mathrm{n}}$ and $R_{\mathrm{t}}$ for limestone based on laboratory tests (Saroglou et al., 2010).

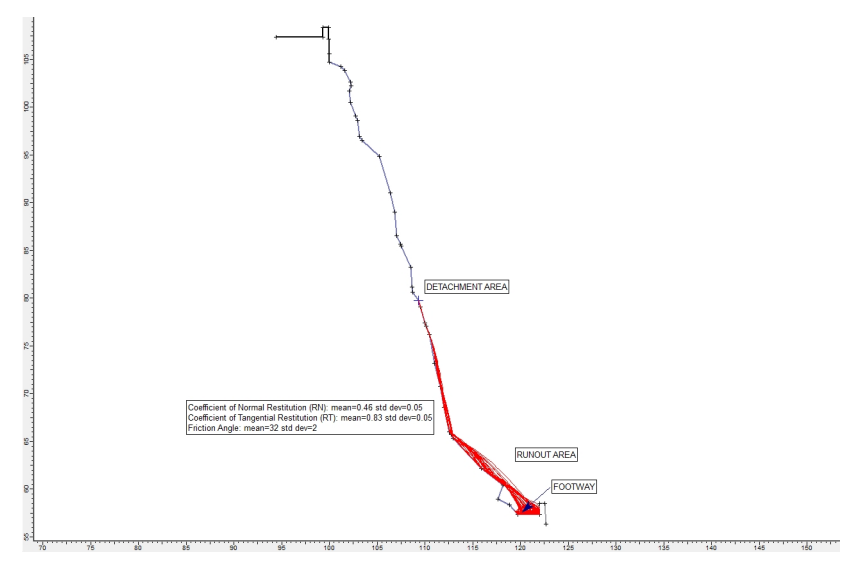

Fig. 8. Back analysis of known rockfall event, which occurred in section $\mathrm{C}$ in 2010.

modern reflector-less total stations), which resulted in a three-dimensional Digital Terrestrial Model (DTM) of the ground surface (Lambrou and Pantazis, 2006). The methodology is mainly based on the capability of the total station to automatically sweep the surface by means of the scanning mode, which takes automatic measurements at defined intervals predetermined by the user window. The advantage is that the coordinates $\mathrm{x}, \mathrm{y}, \mathrm{z}$ of an adequate number of points can be quickly determined. The result of the methodology is the creation of 3-D Digital Terrestrial Model (DTM) of the surface by an accuracy of about $\pm 2 \mathrm{~cm}$.

The height of the potential rockfall source is a minimum of $20 \mathrm{~m}$ above the base of the cliff, while in a few places

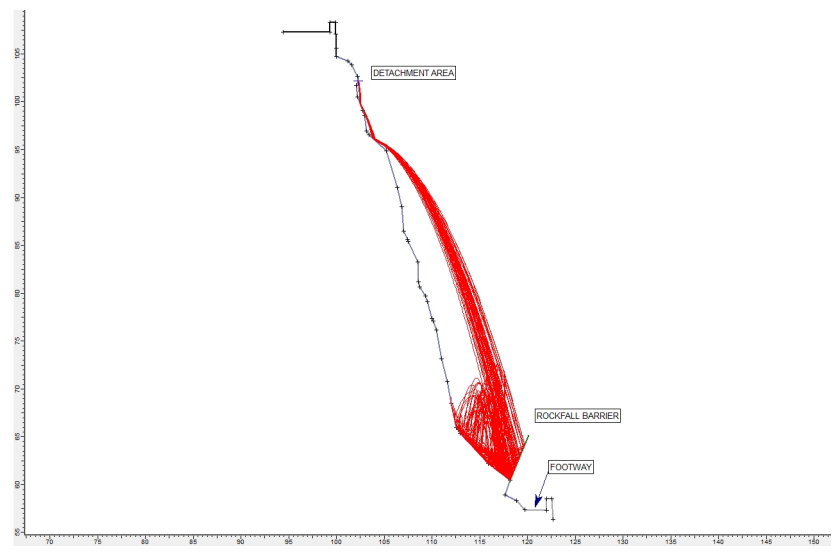

Fig. 9. Rockfall analysis at section C, in Fig. 11.

Table 1. Rockfall parameters of limestone slope face.

\begin{tabular}{lll}
\hline Method & $R_{\mathrm{n}}$ mean value & $R_{\mathrm{t}}$ mean value \\
\hline Back analysis & 0.46 & 0.83 \\
Laboratory test & 0.48 & 0.77 \\
Total mean value & 0.47 & 0.80 \\
\hline
\end{tabular}

it reaches $50 \mathrm{~m}$. The size of the unstable blocks, which are more likely to fall, is between $1.5 \mathrm{~m}^{3}$ and about $4 \mathrm{~m}^{3}$, except the area between Sections A and B (Fig. 10) as well as section $\mathrm{E}$ where the size can be up to $30 \mathrm{~m}^{3}$. In the area shown in Fig. 4, the potentially unstable blocks have very large dimensions.

\subsection{Restitution coefficients of limestone}

In order to model the trajectory of the falling rocks and design the rockfall barriers, it was necessary to calculate efficiently the normal and tangential coefficients of restitution ( $R_{\mathrm{n}}$ and $R_{\mathrm{t}}$, respectively) of the limestone. For this purpose, rebound tests of rock spheres on a limestone plate were performed in the laboratory for a range of slope inclination. Based on the test results, the range of the values of the coefficients of restitution were determined, as presented in Fig. 7. The normal coefficient of restitution, $R_{\mathrm{n}}$, ranges between 0.3 and 0.7 , while the tangential coefficient, $R_{\mathrm{t}}$, between 0.60 and 0.95 (Saroglou et al., 2010).

The mean value of $R_{\mathrm{n}}$ for the whole range of slope inclinations is equal to 0.48 , while for $R_{\mathrm{t}}$ equal to 0.77 . This range agrees well with that proposed by $\mathrm{Wu}(1985)$ and Richards et al. (2001), who notes that the values of $R_{\mathrm{n}}$ are significantly lower than those proposed in literature or in rockfall analysis software.

Additionally, back analysis of a known rockfall event was performed in order to determine the coefficients of restitution and the friction angle of the limestone face. The back analysis was performed in section $\mathrm{C}$, where a rock block with a 


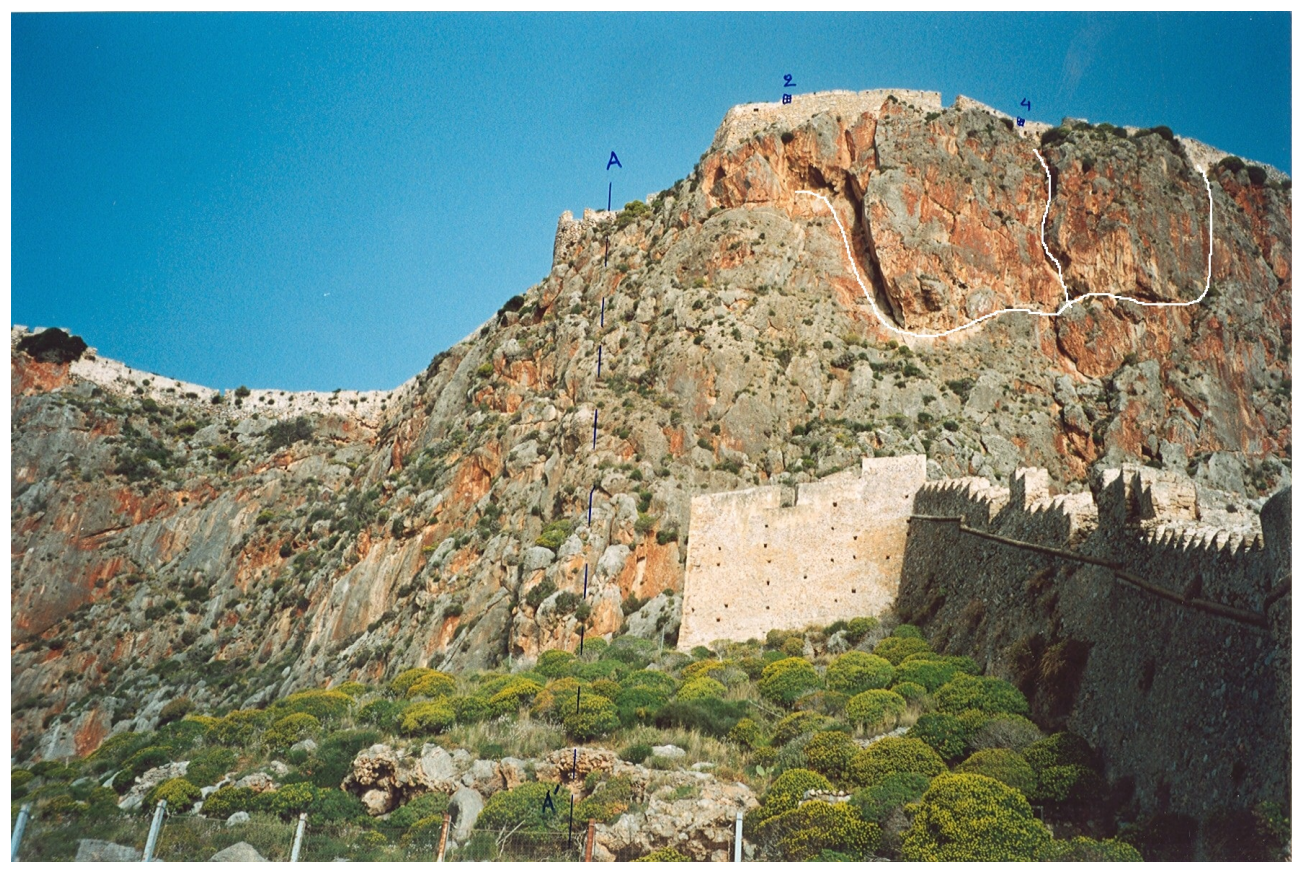

Fig. 10. Photo of a section of the slope having hanging blocks with very large dimensions.

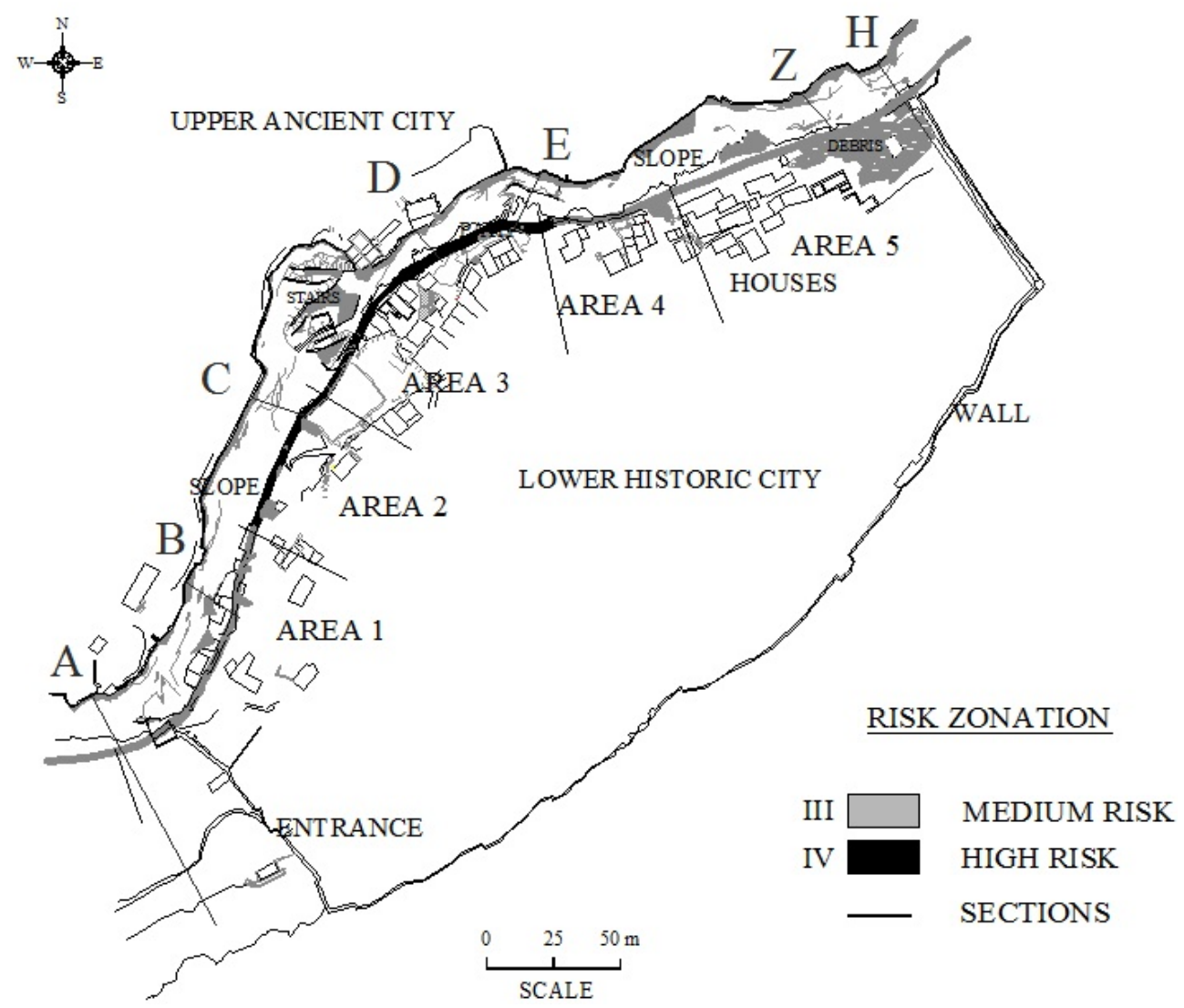

Fig. 11. Risk zonation of rock slope based on proposed rockfall risk rating system. 
Table 2. Rockfall analysis results in different slope sections.

\begin{tabular}{lllll}
\hline $\begin{array}{l}\text { Section } \\
\text { Fig. 11 }\end{array}$ & $\begin{array}{l}\text { Elevation/height } \\
\text { of block } \\
\text { detachment }(\mathrm{m})\end{array}$ & $\begin{array}{l}\text { Location of rockfall } \\
\text { impact }\end{array}$ & $\begin{array}{l}\text { Intensity of } \\
\text { rockfall impact }\end{array}$ & $\begin{array}{l}\text { Barrier energy } \\
\text { required for block } \\
\text { range 2-3 } \mathrm{m}^{3}(\mathrm{~kJ})\end{array}$ \\
\hline A & $+98(46)$ & Access road to castle & Low & 1000-1150 \\
\hline B & $+103(40)$ & Castle wall & Medium & $1250-1850$ \\
$+84(21)$ & Houses and & High & 1950-3000 \\
\hline $\mathrm{C}$ & $+102(40)$ & pedestrian path & High & $410-600$ (on slope) \\
\hline $\mathrm{D}$ & $+93(32)$ & Houses & High & $400-600$ (on slope) \\
\hline $\mathrm{E}$ & $+87(29)$ & Houses & High & $\begin{array}{l}2250-3400 \\
460-600 \text { (on slope) }\end{array}$ \\
\hline $\mathrm{Z}$ & $+98(48)$ & Houses & Low-Medium & $420-650$ \\
\hline $\mathrm{H}$ & $+80(30)$ & & &
\end{tabular}

volume of $1 \mathrm{~m}^{3}$ has fallen in 2010, whose trajectory (detachment location and run-out distance) was known (as shown in Fig. 8).

From the present analyses, it is evident that the values of coefficients of restitution are close to those proposed by Robotham et al. (1995) and Richards et al. (2001) for limestone rocks.

The values of the coefficients of restitution, as determined by the different methods, are presented in Table 1. From the back analysis it was found that the rolling friction angle is equal to $32^{\circ}$.

\subsection{Results of analysis}

The analysis was performed using the software RocFall of Rocscience Inc (1998). The coefficients of normal and tangential restitution for the limestone were determined as presented earlier. The initial velocity of the falls was taken equal to $0.48 \mathrm{~m} \mathrm{~s}^{-1}$ due to seismic triggering (based on the acceleration coefficient of the area according to the Greek Earthquake Resistant Regulations, 2004). An example of the analysis in Section $C$ is shown in Fig. 9. It is evident that the installation of a barrier in locations with an adequate catchment area can protect the structures and human activities at the foot slope.

It should be noted that the width of the zone, just behind the barrier, is very decisive for the impact energy since this portion of the slope provides considerable damping and, therefore, loss in energy. In some locations, such as in the area between sections D and E, there is no space behind the barrier resulting in enhanced impact energy. In such cases, the rockfall barriers in the analysis were installed on the slope face in order to arrest potential falling blocks before their trajectory impacts the houses at the slope foot.
Since the volume of the rocks varies, an analysis was carried out for a range of rock block volumes $2 \mathrm{~m}^{3}$ and $3 \mathrm{~m}^{3}$ and for a range of block detachment heights (between 20 and $50 \mathrm{~m}$ ). The total kinetic energy, which is produced by the falling rock blocks, as calculated at the different sections of the slope, does not exceed $2500 \mathrm{~kJ}$ and only in some locations, as in sections $\mathrm{C}$ and $\mathrm{Z}$, with blocks having a volume greater than $2 \mathrm{~m}^{3}$ resulted in total kinetic energies greater than $2500 \mathrm{~kJ}$. The results of the rockfall analysis for different sections of the slope are presented in Table 2, together with the maximum impact energy at the location of the barrier under consideration and the impact effect of rockfalls for each section.

\section{Slope stabilization}

The necessary support measures can be divided into two categories: (a) those which apply an external force on the rock face e.g., tensioned rock anchors and/or patterned rock bolts, and (b) those which offer protection once the rockfall occurs, mainly rockfall barriers. Other support measures, such as grouting of rock joints with associated drainage, construction of buttresses in overhanging areas and removal of unstable blocks are not always applicable or very difficult to construct on high rock cliffs.

The application of tensioned anchors or pattern bolting in the locations where large individual blocks exist (or spot bolting for smaller ones) at the slope crest is adequate. The application of sprayed concrete is not acceptable due to the archaeological restrictions of the area. The same is true for the installation of steel nets in a number of locations.

As mentioned earlier, the scale of some potential failures is such, that no stabilization measures can minimize or withdraw the risk of a potential rockfall after their application. 
Table 3. Categories of parameters defining the risk and weight of each category.

\begin{tabular}{lll}
\hline $\begin{array}{l}\text { Category of } \\
\text { parameters }\end{array}$ & $\begin{array}{l}\text { Description } \\
\text { in the total risk score }\end{array}$ & $\begin{array}{l}\text { Weight of category } \\
\text { of category }\end{array}$ \\
\hline A & $\begin{array}{l}\text { Geometry of slope and release area position, } \\
\text { slope roughness, presence of vegetation }\end{array}$ & $25 \%$ \\
\hline B & Geology and rockmass conditions & $25 \%$ \\
\hline C & $\begin{array}{l}\text { Potential triggering factors (rainfall, seismicity) } \\
\text { condition of drainage }\end{array}$ & $10 \%$ \\
\hline $\mathrm{D}$ & $\begin{array}{l}\text { Consequences and associated factors, } \\
\text { rockfall history }\end{array}$ & $40 \%$ \\
\hline
\end{tabular}

Even high-energy rockfall barriers would prove insufficient, as in the case of the rock block shown in Fig. 10 detached from the cliff. A possible support solution, in this case, would be to install tensioned wire-rope cables around the rock block to resist its movement.

\section{Rockfall risk assessment}

\subsection{General}

The assessment of rockfall risks along roads and on other human activities is of great importance (Budetta, 2004). In order to assess rockfall risk, a number of rating systems have been developed.

Just to mention, Pierson et al. (1990) have developed the Rockfall Hazard Rating System (RHRS), which is most widely accepted. A similar system is that proposed by Pritchard et al. (2005), who developed a rating methodology which is applied to predict rockfall risk along railways. McMillan and Matheson (1997) have developed the Rock Slope Hazard Index (RSHI) system for highway rock slope inspection in Scotland. Santi et al. (2009) have proposed a modification to the Colorado Rockfall Hazard Rating system, developed initially from Andrew (1994) for highway slopes in Colorado. Hungr and Evans (1999) have applied quantitative risk analysis for determination of total risk on highway and railways in British Columbia, which is based on data on the magnitude and frequency distribution of the rockfall hazards. Hungr et al. (2003) have proposed a new rockfall hazard rating system for use along a railway line, again with a Quantitative Risk Assessment (QRA) procedure.

Vandewater et al. (2005) have proposed a rockfall hazard system for highways giving emphasis on the contribution of geological factors.

Most of the existing systems use hazard and consequence categories. These systems give a reasonable assessment of the relative hazards due to rockfalls from cut slopes adjacent to highways and railways. Thus, they include also the conditions of the anthropgenic cuts and not just those of natural slopes.
Some authors have proposed systems that are applicable to natural slopes, but most are specific oriented. Bolin et al. (2009) have proposed a new assessment system for rockfall risk (ASRFR) in the Wu Gorge area in China, which considers seven factors for hazard and eight factors for consequence.

Another approach for the calculation of risk is presented by Corominas et al. (2005) while Guzzetti and Reichenbach (2004) have used a methodology based on rockfall hazard maps produced by three-dimensional rockfall trajectories to determine risk along a part of the transportation network of Central Italy.

The Austrian Service for Torrent and Avalanche Control (Tartarotti, 2011) proposed a simple risk classification system which relies on four parameters, namely: (a) the probability of presence of an event, (b) vulnerability of structures, (c) the probability of occurrence, and (d) the process and energy class of a rockfall.

\subsection{Proposed rockfall risk rating system}

The rockfall risk rating systems in literature are well documented, but are mostly devoted to reasonable assessment of the relative hazards due to rockfalls from cut slopes adjacent to highways and railways. In the present study, a rockfall risk rating system is proposed which is mostly applicable to the calculation of rockfall risk of natural and man-made slopes and encompasses all those parameters, which are considered important for this purpose. It defines twenty (20) rating parameters, grouped in four (4) major categories according to the hazard and consequences, with a different weight in the assessment of the total risk.

The weight for each category varies, depending on the importance of the parameters involved. More specifically, category A is given a weight of $25 \%$ to the total risk score of a slope, while B $25 \%$, C $10 \%$ and D is given $40 \%$.

The first category of hazard, category A, involves parameters, related to the geometry of the slope (angle, height, slope roughness and vegetation) and the height of the rockfall release areas. Category B parameters refer to the geological 
Table 4. Parameters of all categories and rating of proposed rockfall rating system for natural rock slopes to define risk.

\begin{tabular}{|c|c|c|c|c|c|c|c|c|c|}
\hline Parameter & $\begin{array}{l}\text { Category/ } \\
\text { parameter }\end{array}$ & \multicolumn{7}{|c|}{ Rating } & \multirow{2}{*}{$\begin{array}{l}\text { Score } \\
\text { (Multiply rating } \\
\text { with weight } \\
\text { factor of } \\
\text { parameter) }\end{array}$} \\
\hline 1. Slope angle $\left(^{0}\right)$ & \multirow[t]{2}{*}{$\mathrm{A} / 7 \%$} & \multicolumn{2}{|l|}{$25-40$} & \multicolumn{2}{|c|}{ Medium 40-50 } & \multicolumn{2}{|c|}{ High $50-60$} & $\begin{array}{l}\text { Very high }>60 \\
\text { Overhanging }\end{array}$ & \\
\hline Rating & & \multicolumn{2}{|l|}{10} & \multicolumn{2}{|c|}{30} & \multicolumn{2}{|c|}{60} & 100 & \\
\hline 2. Slope height (m) & \multirow{2}{*}{$\mathrm{A} / 4 \%$} & \multicolumn{2}{|l|}{$<15$} & \multicolumn{2}{|c|}{$15-30$} & \multicolumn{2}{|c|}{$30-60$} & $>60$ & \\
\hline Rating & & \multicolumn{2}{|l|}{10} & \multicolumn{2}{|c|}{30} & \multicolumn{2}{|c|}{60} & 100 & \\
\hline $\begin{array}{l}\text { 3. Release area height } \\
\text { ( } \mathrm{H} \text { is total height of slope) }\end{array}$ & \multirow[t]{2}{*}{$\mathrm{A} / 7 \%$} & \multicolumn{2}{|c|}{$\begin{array}{c}\text { Rockfalls from low slope } \\
\text { areas }(\mathrm{H} / 4)\end{array}$} & \multicolumn{2}{|c|}{$\begin{array}{l}\text { Rockfalls from } \\
\text { middle slope areas } \\
(\mathrm{H} / 2)\end{array}$} & \multicolumn{2}{|c|}{$\begin{array}{c}\text { Rockfalls from middle to upper } \\
\text { slope areas }(3 \mathrm{H} / 2)\end{array}$} & $\begin{array}{c}\text { Rockfalls from whole } \\
\text { slope }(\mathrm{H})\end{array}$ & \\
\hline Rating & & \multicolumn{2}{|l|}{10} & 3 & & \multicolumn{2}{|c|}{60} & 100 & \\
\hline 4. Slope roughness & \multirow[t]{2}{*}{$\mathrm{A} / 3 \%$} & \multicolumn{2}{|c|}{$\begin{array}{l}\text { Rough, planar, (friction } \\
\text { reduces acceleration) }\end{array}$} & \multicolumn{2}{|c|}{$\begin{array}{c}\text { Planar smooth } \\
\text { (helps acceleration) }\end{array}$} & \multicolumn{2}{|c|}{$\begin{array}{l}\text { Rough, presence of narrow } \\
\text { benches, (helps bouncing) }\end{array}$} & $\begin{array}{c}\text { Very rough, presence } \\
\text { of narrow benches }\end{array}$ & \\
\hline Rating & & \multicolumn{2}{|l|}{10} & \multicolumn{2}{|c|}{30} & \multicolumn{2}{|c|}{60} & 100 & \\
\hline 5. Vegetation of slope & $\mathrm{A} / 4 \%$ & $\begin{array}{l}\text { Dense vegetatio } \\
\text { occurrence of high }\end{array}$ & & $\begin{array}{l}\text { Low } \\
\text { vegetatio }\end{array}$ & $\begin{array}{l}\text { d } \\
\text { sshes }\end{array}$ & Sparse v & egetation & No vegetation & \\
\hline Rating & & 10 & & 3 & & 6 & 0 & 100 & \\
\hline $\begin{array}{l}\text { int roughness / Filling material in } \\
\text { joints/Joint Opening }\end{array}$ & $\mathrm{B} / 6 \%$ & Rough, stepped & & Smooth, s & & $\begin{array}{l}\text { Undulating or } \\
\text { filling material } \\
\text { with angular } \\
\text { fragments } \\
\text { independent of } \\
\text { roughness or } \\
\text { moderate } \\
\text { opening of } \\
\text { joints } \\
2.5 \text { to } 10 \mathrm{~mm} \\
\end{array}$ & \begin{tabular}{|} 
Slightly rough \\
planar or filling \\
with stiff clay \\
$>5 \mathrm{~mm}$ \\
independent of \\
roughness or \\
very wide \\
opening of \\
joints \\
$10-100 \mathrm{~mm}$ \\
\end{tabular} & $\begin{array}{c}\text { Smooth planar or } \\
\text { filling soft clay }>5 \mathrm{~mm} \\
\text { independent of } \\
\text { roughness or } \\
\text { extremely wide } \\
\text { opening }>100 \mathrm{~mm}\end{array}$ & \\
\hline Rating & & 10 & & 15 & & 30 & 60 & 100 & \\
\hline $\begin{array}{l}\text { 7. Joint Orientation } \\
\text { (or combination of joints) }\end{array}$ & $\mathrm{B} / 5 \%$ & Favorable fo & tabil & lity & & Ioderate & Adverse & Very adverse & \\
\hline Rating & & 10 & & & & 30 & 60 & 100 & \\
\hline 8. Joint Persistence (m) & $\mathrm{B} / 4 \%$ & Very low $<1 \mathrm{~m}$ & & w $1-2 \mathrm{~m}$ & Moc & erate $2-5 \mathrm{~m}$ & High $5-10 \mathrm{~m}$ & Very high $>10 \mathrm{~m}$ & \\
\hline Rating & B/4\% & 10 & & 15 & & 30 & 60 & 100 & \\
\hline $\begin{array}{l}\text { 9. Joint compressive strength } \\
\text { (JCS, MPa, affects friction on joints) }\end{array}$ & $\mathrm{B} / 1 \%$ & $>30$ & & $20-30$ & & $5-2$ & & $<5$, weathered & \\
\hline Rating & & 10 & & 30 & & 60 & & 100 & \\
\hline $\begin{array}{l}\text { 10. Strength of intact rock } \\
\text { (MPa, helps splitting of falling } \\
\text { blocks if strength is low Facilitates } \\
\text { bouncing if strength is high) }\end{array}$ & $\mathrm{B} / 1 \%$ & $<10$ & & $10-30$ & & $30-$ & & $>60 \mathrm{MPa}$ & \\
\hline Rating & & 10 & & 30 & & 60 & & 100 & \\
\hline $\begin{array}{l}\text { 11. Rock mass blockiness / } \\
\text { Block volume }\left(\mathrm{m}^{3}\right)\end{array}$ & $\mathrm{B} / 4 \%$ & $<1$ & & $1-2.5$ & & $2.5-4.0$ & $4.0-8.0$ & $>8.0$ & \\
\hline Rating & & 10 & & 15 & & 30 & 60 & 100 & \\
\hline $\begin{array}{l}\text { 12. Estimated number of blocks (for } \\
\text { the width of slope under assessment) }\end{array}$ & B/2\% & Null & & $1-5$ & & $5-10$ & & $>10$ & \\
\hline Rating & & 10 & & 30 & & 60 & & 100 & \\
\hline 13. Karstic features & $\mathrm{B} / 2 \%$ & No karst & & Sparse & & $\begin{array}{r}\text { Moder } \\
\text { undermined c }\end{array}$ & ate & $\begin{array}{c}\text { Frequent } \\
\text { Undermined conditions }\end{array}$ & \\
\hline Rating & & 10 & & 30 & & 60 & & 100 & \\
\hline 14. Rainfall conditions and intensity & $\mathrm{C} / 3 \%$ & Seldom & & Sparsely & & seasonal & often & $\begin{array}{c}\text { Very often, during } \\
\text { whole year }\end{array}$ & \\
\hline Rating & & 10 & & 15 & & 30 & 60 & 100 & \\
\hline $\begin{array}{l}\text { 15. Permeability/ Condition of slope } \\
\text { drainage }\end{array}$ & $\mathrm{C} / 3 \%$ & Very high & & High & & Moderate & Low & Very low & \\
\hline Rating & & 10 & & 15 & & 30 & 60 & 100 & \\
\hline
\end{tabular}


Table 4. Continued.

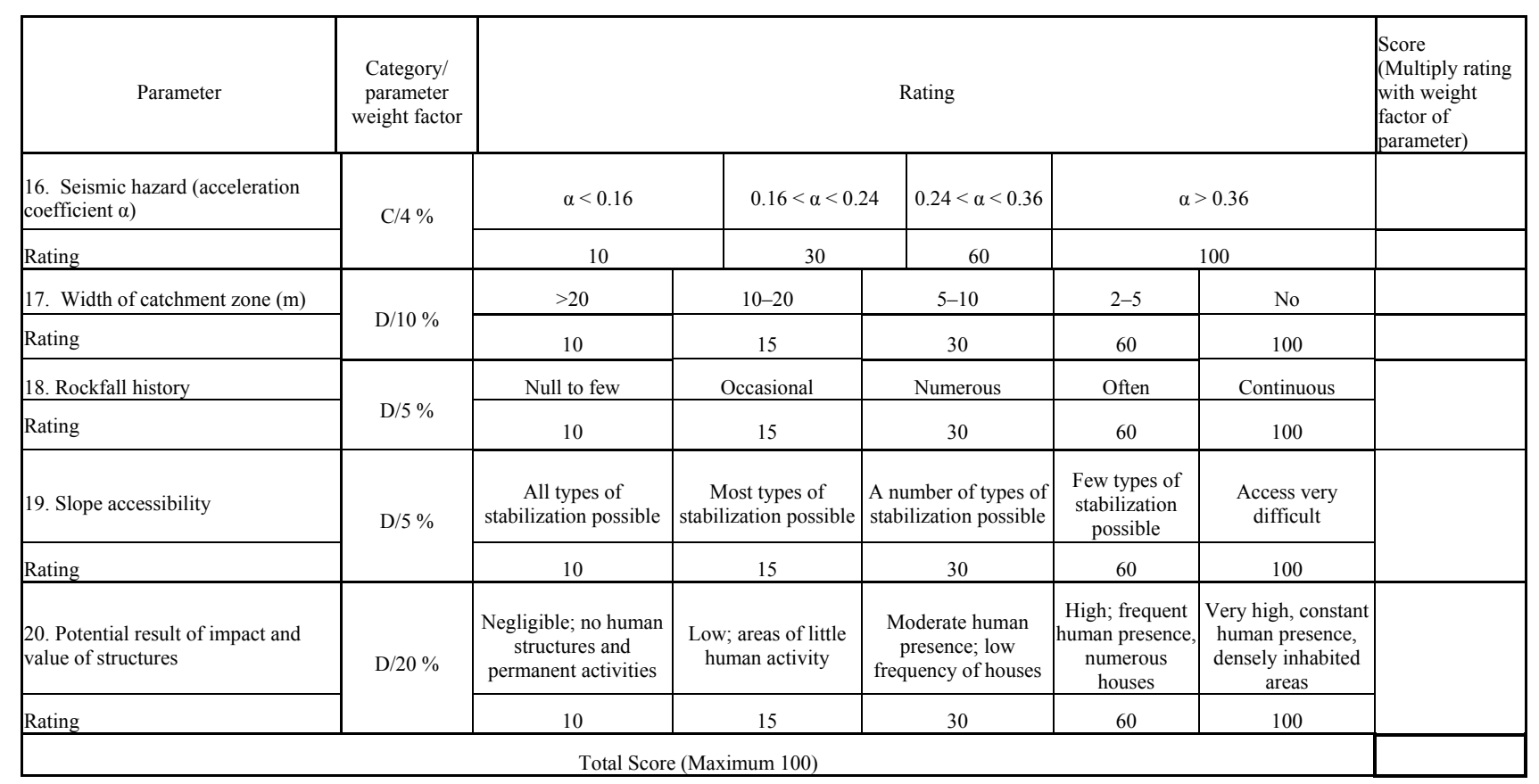

Table 5. Rockfall risk classes and indicative protection measures

\begin{tabular}{llll}
\hline Risk Class & $\begin{array}{l}\text { Total weighted } \\
\text { score 1-100 }\end{array}$ & Risk & Indicative protection measures (the choice is site specific) \\
\hline I & $<20$ & Very Low & Not necessary. May be sparse spot interventions. \\
\hline II & $21-40$ & Low & In limited extent \\
\hline III & $41-60$ & Medium & $\begin{array}{l}\text { Light measures (such as bolts, nets, removal of unstable blocks, } \\
\text { simple light fences) }\end{array}$ \\
\hline IV & $61-80$ & High & $\begin{array}{l}\text { Combination of active (such as bolts, anchors) and passive (such } \\
\text { as nets, wire rope cables, buttress walls, fences removal of } \\
\text { unstable blocks) measures }\end{array}$ \\
\hline V & $81-100$ & Very High & $\begin{array}{l}\text { Critical state of stability, combination of generalized or/and } \\
\text { strong active and passive measures. Residual risk to be } \\
\text { accepted. }\end{array}$ \\
\hline
\end{tabular}

and rock mass conditions of the slope. These parameters describe the condition of the rock discontinuities, the intact rock strength, presence of karst and the block volume and number of potential blocks. Category $\mathrm{C}$ parameters relate to the potential triggering factors (rainfall, seismicity of the area) and drainage conditions of groundwater on the rock stability. Category D parameters refer to the consequences impact on structures and associated elements, as well as the accessibility of the slope. The categories and their weight in the total risk score are presented in Table 3.
The proposed risk rating system has been developed on an empirical basis, with the weight of categories and parameters and the parameter rating, based on reasonable geoengineering judgment and reasonable facts. The proposed risk system was designed with special emphasis on rating of natural rock slopes, which pose a rockfall hazard on human structures and activities, such as in the case of the historic city of Monemvasia.

Each parameter has an internal, exponential, increase of rating, between 10 and 100, as one moves from favourite to adverse conditions. The parameter is rated and then is 
Table 6. Application of proposed risk rating system for the Monemvasia historic site high limestone cliff (The value in parenthesis is the unweighted rating for each parameter).

\begin{tabular}{|c|c|c|c|c|c|c|c|}
\hline \multirow{2}{*}{$\begin{array}{l}\text { Area (Fig. 1b) } \\
\text { Section on slopes (Fig. 11) }\end{array}$} & \multirow{2}{*}{1} & \multicolumn{2}{|c|}{2} & \multicolumn{2}{|l|}{3} & 4 & \multirow{2}{*}{$\begin{array}{l}5 \\
\mathrm{H}\end{array}$} \\
\hline & & B & $\mathrm{C}$ & $\mathrm{D}$ & $\mathrm{E}$ & $\mathrm{Z}$ & \\
\hline \multicolumn{8}{|l|}{ Parameter } \\
\hline 1 Slope angle & $\begin{array}{l}4.2 \\
(60)\end{array}$ & $\begin{array}{l}7.0 \\
(100)\end{array}$ & $\begin{array}{c}7.0 \\
(100)\end{array}$ & $\begin{array}{l}7.0 \\
(100)\end{array}$ & $\begin{array}{l}7.0 \\
(100)\end{array}$ & $\begin{array}{l}4.2 \\
(60)\end{array}$ & $\begin{array}{l}4.2 \\
(60)\end{array}$ \\
\hline 2 Slope height & $\begin{array}{c}2.4 \\
(60)\end{array}$ & $\begin{array}{l}2.4 \\
(60)\end{array}$ & $\begin{array}{l}2.4 \\
(60)\end{array}$ & $\begin{array}{l}2.4 \\
(60)\end{array}$ & $\begin{array}{l}1.2 \\
(60)\end{array}$ & $\begin{array}{l}2.4 \\
(60)\end{array}$ & $\begin{array}{l}2.4 \\
(60)\end{array}$ \\
\hline 3 Release area height & $\begin{array}{c}7.0 \\
(100)\end{array}$ & $\begin{array}{l}7.0 \\
(100)\end{array}$ & $\begin{array}{c}7.0 \\
(100)\end{array}$ & $\begin{array}{l}4.2 \\
(60)\end{array}$ & $\begin{array}{l}7.0 \\
(100)\end{array}$ & $\begin{array}{l}2.1 \\
(30)\end{array}$ & $\begin{array}{l}7.0 \\
(100)\end{array}$ \\
\hline 4 Slope roughness & $\begin{array}{l}1.8 \\
(60)\end{array}$ & $\begin{array}{l}1.8 \\
(60)\end{array}$ & $\begin{array}{c}3.0 \\
(100)\end{array}$ & $\begin{array}{l}3.0 \\
(100)\end{array}$ & $\begin{array}{l}3.0 \\
(100)\end{array}$ & $\begin{array}{l}3.0 \\
(100)\end{array}$ & $\begin{array}{l}3.0 \\
(100)\end{array}$ \\
\hline $\begin{array}{l}5 \text { Vegetation of slope } \\
6 \text { Roughness of joints/filling } \\
\text { of joints/opening of joints } \\
7 \text { Orientation of joints } \\
8 \text { Persistence of joints } \\
9 \text { Joint strength } \\
10 \text { Strength of intact rock }\end{array}$ & & & & $\begin{array}{l}1.5 \\
1.2 \\
1.0 \\
1.0\end{array}$ & $\begin{array}{l}0) \\
0) \\
0) \\
0)\end{array}$ & & \\
\hline 11 Block volume & $\begin{array}{c}4.0 \\
(100)\end{array}$ & $\begin{array}{l}4.0 \\
(100)\end{array}$ & $\begin{array}{c}4.0 \\
(100)\end{array}$ & $\begin{array}{l}4.0 \\
(100)\end{array}$ & $\begin{array}{l}2.4 \\
(60)\end{array}$ & $\begin{array}{l}4.0 \\
(100)\end{array}$ & $\begin{array}{l}1.2 \\
(30)\end{array}$ \\
\hline 12 Estimated number of blocks & $\begin{array}{l}0.6 \\
(30)\end{array}$ & $\begin{array}{l}1.2 \\
(60)\end{array}$ & $\begin{array}{c}0.6 \\
(30)\end{array}$ & $\begin{array}{l}0.6 \\
(30)\end{array}$ & $\begin{array}{l}0.6 \\
(30)\end{array}$ & $\begin{array}{l}1.2 \\
(60)\end{array}$ & $\begin{array}{l}0.6 \\
(30)\end{array}$ \\
\hline 13 Karstic features & $\begin{array}{l}0.6 \\
(30)\end{array}$ & $\begin{array}{l}0.6 \\
(30)\end{array}$ & $\begin{array}{l}0.6 \\
(30)\end{array}$ & $\begin{array}{l}2.0 \\
(100)\end{array}$ & $\begin{array}{l}1.2 \\
(60)\end{array}$ & $\begin{array}{l}2.0 \\
(100)\end{array}$ & $\begin{array}{l}1.2 \\
(60)\end{array}$ \\
\hline $\begin{array}{l}14 \text { Rainfall } \\
15 \text { Permeability } \\
16 \text { Seismicity }\end{array}$ & \multicolumn{7}{|c|}{$\begin{array}{l}0.45(15) \\
0.4(100)\end{array}$} \\
\hline 17 Catchment zone width & $\begin{array}{l}1.0 \\
(10)\end{array}$ & $\begin{array}{l}10 \\
(100)\end{array}$ & $\begin{array}{c}10 \\
(100)\end{array}$ & $\begin{array}{l}10 \\
(100)\end{array}$ & $\begin{array}{l}1.5 \\
(15)\end{array}$ & $\begin{array}{l}3.0 \\
(30)\end{array}$ & $\begin{array}{l}10 \\
(100)\end{array}$ \\
\hline 18 Rockfall history & \multicolumn{7}{|c|}{$1.5(30)$} \\
\hline 19 Accessibility & $\begin{array}{l}3.0 \\
(60)\end{array}$ & $\begin{array}{l}5.0 \\
(100)\end{array}$ & $\begin{array}{c}5.0 \\
(100)\end{array}$ & $\begin{array}{l}5.0 \\
(100)\end{array}$ & $\begin{array}{l}3.0 \\
(60)\end{array}$ & $\begin{array}{l}3.0 \\
(60)\end{array}$ & $\begin{array}{l}1.5 \\
(30)\end{array}$ \\
\hline 20 Potential impact & $\begin{array}{l}3.0 \\
(15)\end{array}$ & $\begin{array}{l}20 \\
(100)\end{array}$ & $\begin{array}{c}20 \\
(100)\end{array}$ & $\begin{array}{l}20 \\
(100)\end{array}$ & $\begin{array}{l}12.0 \\
(60)\end{array}$ & $\begin{array}{l}12.0 \\
(60)\end{array}$ & $\begin{array}{l}3.0 \\
(15)\end{array}$ \\
\hline Score on 10 to 100 scale & 41.35 & 72.75 & 73.35 & 71.95 & 52.65 & 50.65 & 47.85 \\
\hline Risk & Medium & High & High & High & Medium & Medium & Medium \\
\hline
\end{tabular}

multiplied by a respective weight factor. Finally, the total risk score is calculated by summing the individual score of each parameter. The parameters of each category, the weight factor for each parameter and their rating are presented in Table 4.
Based on the rating method proposed, a slope with the highest risk will have a total weighted score of 100 in a 10 to 100 scale. In order to classify the risk against rockfalls and decide on protection measures, the proposed risk classification of rock slopes has five categories, very low to very high risk, as presented in Table 5. 


\section{Rockfall risk assessment for Monemvasia rock slope}

The Rockfall Risk Rating system was applied at selected locations along the rock cliff of Monemvasia, since the parameter rating differs for each slope area. The locations coincide with the topographical sections (A to H, Fig. 11) as presented previously. The application of this risk rating is shown in Table 6 .

The parameters that vary from one location to another are: (a) the volume and number of rock blocks, (b) the spacing and persistence of discontinuities, (c) the height of the release area, (d) the width of the available catchment zone, and (e) the existence of structures or human activity at the underlying area. The slope height and angle of Monemvasia slopes do not vary significantly. As it can be seen from the application of the risk system, 10 parameters out of 20 have the same rating for the Monemvasia slope.

The result of the application is a risk zonation of the cliff against rockfall occurrence, presented on the risk map shown in Fig. 11. The map depicts the areas having a medium and high risk due to either increased number of existing unstable blocks or restricted area for their catchment or combination of both.

The risk in section $\mathrm{A}$ and in the area between sections $\mathrm{A}$ and B (area 1) is medium. This area has very restricted catchment zone and the installation of barriers will be on the slope foot. However, the impact on the derelict structures in this area is relatively low, hence the risk is medium.

The slope foot area between sections B and E (area 2 and 3) presents high risk due to the numerous unstable blocks on the cliff and the proximity of structures as well as human activity (stairs to upper city). The area between sections $\mathrm{E}$ and $\mathrm{H}$ (area 4 and 5) has medium risk, due to the wide catchment zone at the base, which offers ideal conditions for installation of barriers.

The proposed system has to be further developed and ratified by back analysis for the optimum adjustment of the weight of the big variety of parameters involved. This could be the case of other rock slopes, where most of the parameters may have a significant range, in order to assess the sensitivity of each parameter in the determination of the total risk.

\section{Conclusions}

The rock slope stability of the high limestone cliff overhanging the historical site of Monemvasia promontory in Peloponnese in southern Greece was studied based mainly on kinematic analysis of the unstable blocks and calculation of their rockfall trajectories. In the case of blocks having weights higher than $10 \mathrm{tn}$, the installation of high capacity rockfall barriers cannot remove the hazard due to impact of falling rocks on structures, either because the impact energy is extremely high or the catchment zone is not sufficient for optimized protection. Therefore, the application of active support measures, such as bolts and wire rope nets will be necessary.

In order to calculate the potential risk of the rockfalls, a rating system for natural rock slopes was proposed and the locations with maximum risk are defined. This system involves 20 parameters, appropriately weighted, grouped in categories according to the geometry of the slope, the geological conditions, the potential triggering mechanisms of the rockfall and the consequences of the hazard. Support measures suggestions associated with the proposed risk rating assessment. An application of the proposed system is presented for the Monemvasia cliff. The proposed system has to be further developed and ratified by back analysis for the optimum adjustment of the weight of the big variety of parameters involved.

Acknowledgements. The research is the result of a project of the National Technical University of Athens funded by the Greek Ministry of Culture.

Edited by: F. Luino

Reviewed by: two anonymous referees

\section{References}

Andrew, R. D.: The Colorado Rockfall Hazard Rating System, Colorado Dept. of Transportation, Report \# CTI-CDOT-2-94, 1994.

Bolin, H., Lide, C., Xuanming, P., Guanning, L., Xiaoting, C., Haogang, D., and Tianci, L.: Assessment of the risk of rockfalls in Wu Gorge, Three Gorges, China. Landslides, 7, 1-11, doi:10.1007/s10346-009-0170-7, 2010.

Budetta, P.: Assessment of rockfall risk along roads, Nat. Hazards Earth Syst. Sci., 4, 71-81, doi:10.5194/nhess-4-71-2004, 2004.

Corominas, J, Copons, R., Moya, J., Vilaplana, J. M., Altimir, J., and Amigó J.: Quantitative assessment of the residual risk in a rockfall protected area, Landslides, 2, 343-357, 2005.

Greek Earthquake Resistant Regulations: Earthquake Planning and Protection Organisation, 2004.

Guzzetti, F. and Reichenbach, P.: Rockfall Hazard and Risk Assessment Along a Transportation Corridor in the Nera Valley, Central Italy, Environ. Manage., 34, 2, 191-208, 2004.

Hungr, O., Evans, S. G., and Hazzard, J.: Magnitude and frequency of rockfalls and rock slides along the main transportation corridors of southwestern British Columbia, Can. Geotech. J., 36, 224-238, 1999.

Hungr, O., Fletcher, L., Jakob, M., MacKay, C., and Evans, S. G.: A system of rockfall and rock slide Hazard Rating for a railway, Proc. 3rd Canadian Conference on Geotechnique and Natural Hazards (Geohazards 2003), Canada, 2003.

Lambrou, E. and Pantazis, G.: A new geodetic methodology for the accurate documentation and monitoring of inaccessible surfaces, Proc. of 12th FIG Symposium, Baden, Germany, Digital proceedings Austria, 2006.

Marinos, P. and Koukis, G.: The Engineering Geology of Ancient Works, Monuments and Historical Sites, Balkema, 4, Proc. of Int. Symp. of Greek National Group of IAEG, 1998. 
Marinos, P. and Rondoyanni Th.: The archaeological site of Delphi, Greece: a site vulnerable to earthquakes, rockfalls and landslides, Proc. of the 1st General Assembly of the international consortium on Landslides: Landslides-Risk analysis and sustainable disaster management (2001), edited by: Sassa, K., Springer, Kyoto, ch. 31, 241-249, 2005.

Marinos, P. and Tsiambaos, G.: Earthquake triggering rockfalls affecting historic monuments and a traditional settlement in Skyros Island, Greece. Proc. of the International Symposium: Landslide risk mitigation and protection of cultural and natural heritage, Kyoto, Japan, 343-346, 2002.

Marinos, P., Kavvadas, M., Tsiambaos, G., and Saroglou, H.: Rock slope stabilization in Mythimna castle, Lesvos island, Greece, 1st European Conference on landslides, Balkema, edited by: Rybar Stemberk \& Wagner, Prague, 635-639, 2002.

Marinos, P., Tsiambaos, G., Saroglou, H., and Marinos, V.: Rockfall hazard and risk for a high promontory: Monemvasia historical site, Greece, Proc. of 1st World Landslide Forum Landslides - Disaster Risk Reduction, edited by: Kyoji, S. and Canuti, P., Springer, XVIII, 59-62, ISBN 978-3-540-69966-8, 2009.

McMillan, P. and Matheson, G. D.: A two stage system for highway rock slope assessment, Int. J. Rock. Mech. Min. Geomechanics Abstr., 34, 3-4, 196, 1997.

Pritchard, M., Porter, M., Savigny, W., Bruce, I., Oboni, F., Keegan, T., and Abbott, B.: CN rockfall hazard risk management system: Experience, enhancements, and future direction. Landslide Risk Management: Proc. of the Int. Conference on Landslide Risk Management, Vancouver, Balkema, 2005.
Pierson, L. A., Davis, S. A., and Van Vickle, R.: Rockfall Hazard Rating System Implementation Manual. Federal Highway Administration Report FHWA-OR-EG-90-01. FHWA, U.S. Department of Transportation, 1990.

Richards, L. R., Peng, B., and Bell, D. H.: Laboratory and field evaluation of the normal coefficient of restitution for rocks, Proc. of. Int. Symp. Rock Mechanics a Challenge for Society, 149156, edited by: Särkkä, P. and Eloranta, P., 2001.

Rocscience Inc: RocFall, User's Guide, 1998-2002.

Robotham, M. E., Wang, H., and Walton, G.: Assessment of risk from rockfall from active and abandoned quarry slopes, I.M.M., Section A., 104, 25-33, 1995.

Santi, M. P., Russell, P. C., Higgins, D. J., and Spriet, I. J.: Modification and statistical analysis of the Colorado Rockfall Hazard Rating System, Eng. Geol., 104, 55-65, 2009.

Saroglou, H., Mpekri, E., and Tsiambaos, G.: Determination of Critical Parameters of Geological Formations Used in Studying Rockfall Impacts on Rock Slopes, Proc. of 6th Hellenic Congress of Geotechnical and Geoenvironmental Engineering, 2, 43-50, 2010.

Tartarotti, Th.: Standardized risk assessment of rockfall processes for protection planning. Austrian Service for Torrent and Avalanche Control, Rocexs2011, Interdisciplinary Workshop on Rockfall protection, Innsbruck 2011, 2011.

Vandewater, C. J., Dunne, W. M., Mauldon, M., Drumm, E. C., and Batemann, V.: Classifying and assessing the geologic contribution to rockfall hazard, Environ. Eng. Geosci., 11, 141-154, 2005.

Wu, S. S.: Rockfall evaluation by computer simulation, Transp. Res. Rec., 1031, 1-5, 1985. 